\title{
INNOWACJE A PSEUDOINNOWACJE. NIEKTÓRE NORMATYWNE ZAŁOŻENIA DYSTYNKCJI
}

\begin{abstract}
Innovations versus pseudo-innovations: Some normative assumptions of the distinction

The general objective of the work is to identify the axiological assumptions of the concept of innovation. The study shows their presence in the arguments justifying the claim that something is or is not an innovation. The literature and logical analyses shall achieve this goal. They should also indicate essential differences between innovation and pseudo-innovation. The practical goal is to show the role that these assumptions play in decision-making and planning innovation strategies.
\end{abstract}

Keywords: ethics, efficiency, utility, innovation, pseudo-innovations, quality management

\section{Streszczenie}

Teoretycznym celem pracy jest identyfikacja aksjologicznych założeń pojęcia innowacji. Ukazana zostanie ich obecność w rozumowaniach uzasadniających twierdzenie, że coś jest innowacją lub nią nie jest. Cel zrealizowano w drodze literaturowej i logicznej analizy przykładowych teorii zmian. W tym kontekście została ukazana różnica między innowacjami a pseudoinnowacjami. Praktycznym celem pracy jest określenie roli, jaką te założenia odgrywają w podejmowaniu decyzji i planowaniu strategii dotyczących zmian.

Słowa kluczowe: etyka, wydajność, pożytek, innowacje, pseudoinnowacje, zarządzanie wartością 


\section{Wprowadzenie}

Pojęcie innowacji odgrywa ważną rolę w zarządzaniu - oznacza ideał i kierunek zmian, np. rozwoju gospodarki i kształcenia [Kożuch, 2010; Okoń-Horodyńska, 2008]. Dlatego termin „innowacja” i jego derywaty (,innowacyjny”, „innowacyjność" itp.) mają pozytywną konotację - sugerują, że to, co nimi oznaczone, jest cenne, pożyteczne, warte realizacji, inwestycji, swojej ceny itp. $Z$ tego powodu określenia te są modne i używane do promocji, np. w reklamie. Gdy są nadużywane, ich sens zaczyna być chwiejny, stają się wieloznaczne i bezużyteczne w teorii i praktyce zarządzania [Berkun, 2008]. Dlatego wprowadzono rozróżnienie na innowacje w sensie ścisłym i podobne do nich, ale nimi niebędące zjawiska, określane mianem pseudoinnowacji [Walshe, 2009]. Dystynkcja opiera się na rozstrzygnięciach definicyjnych określających specyfikę zjawiska innowacji. Niniejszy tekst dotyczy niektórych etycznych założeń, które pełnią tę rolę.

„Etycznymi założeniami” nazywa się rozstrzygnięcia dotyczące tego, które dobra (nazywane dalej wartościami) są najcenniejsze i autoteliczne (wewnętrzne, łac. intrinsece, ang. intrinsic, niem. Eigenwerte - cenione lub cenne dla nich samych, niezależnie od tego, czy służą osiągnięciu innych niż one celów działania). Takimi wartościami są np. istnienie i godność osoby w teoriach personalizmu, wolność jednostki w koncepcjach liberalizmu etycznego, szczęście w teorii eudajmonizmu. Wartości autoteliczne odróżnia się od wartości i n $\mathrm{strumentalny} \mathrm{ch,} \mathrm{które} \mathrm{są} \mathrm{cenne} \mathrm{lub} \mathrm{cenione} \mathrm{jedynie} \mathrm{dlatego,} \mathrm{że} \mathrm{są} \mathrm{środ-}$ kiem (narzędziem) w drodze do osiągnięcia i realizacji jakiegoś innego celu niż one [Schroeder, 2012; Świtała, 2015; Zimmerman, 2001]. To odróżnienie (wartości autotelicznych od instrumentalnych) nie implikuje rozstrzygnięć ontologicznych - możne funkcjonować w kontekście etycznego realizmu lub antyrealizmu, relatywizmu lub antyrelatywizmu etycznego w różnych wariantach tych teorii [Brandt, 1967; Brown, 2008; Garnett, 1944; Gowans, 2012; Hollis, Lukes, 1982; Jarvie, 1983: 50-69; Swoyer, 2014; Westacott, 2012].

Teoretycznym celem pracy jest identyfikacja etycznych założeń teorii i ocen innowacji. Cel zrealizowano w drodze literaturowej i logicznej analizy pojęcia innowacji. Nie przesądzi ona tego, które etyczne założenia należy wybrać. Wskazana zostanie jedynie ich obecność w rozumowaniach uzasadniających twierdzenie, że coś jest innowacją lub nią nie jest. Praktycznym celem pracy jest ukazanie roli tych założeń w planowaniu zmian.

W niniejszym studium innowacjami nazywa się zmiany (produktowe, wdrożeniowe, organizacyjne, marketingowe itp., np. stworzenie nowego produktu, zastosowanie nowej technologii, wykorzystanie nowego surowca, reorganizacja firmy) lub ich projekty, które spełniają trzy warunki (każdy z nich jest warunkiem koniecznym, a ich koniunkcja jest warunkiem wystarczającym innowacji):

a) nowość: są nowe, nie było ich wcześniej (innowacje ewolucyjne modyfikują znane, zaś innowacje rewolucyjne wprowadzają nieznane przedtem rozwiązania);

b) skuteczność: stanowią rozwiązanie jakiegoś problemu; 
c) pożytek: dają więcej korzyści niż strat, a przewaga korzyści nad stratami jest większa niż w przypadku innych dostępnych rozwiązań.

Termin „,innowacja” jest aktualnie wieloznaczny i można go rozumieć inaczej, niż zaproponowano [Berkun, 2008; Dance, 2008]. Układ wymienionych wyżej warunków to regulująca definicja, przez postulaty określające znaczenie terminu „innowacja” używanego w niniejszej pracy'. Uznanie czegoś za innowację w takim sensie implikuje jej pozytywną ocenę pod względem nowości, skuteczności i pożyteczności. Pseudoinnowacje spełniają niektóre $\mathrm{z}$ tych warunków, ale nie wszystkie. Na przykład są nowe i skuteczne, ale nie są pożyteczne (rozwiązują jakiś nieistotny problem lub robią to w sposób szkodliwy społecznie); są skuteczne i pożyteczne, ale nie są nowe (powielają wcześniejsze rozwiązania w nowym kontekście działania; są nowe, ale nie są ani skuteczne (nie rozwiązują żadnego problemu), ani pożyteczne itd. Pseudoinnowacje mogą przynosić komuś (np. osobie, grupie, organizacji) zysk. Na przykład w wyniku odpowiedniej promocji mogą uzyskać dotacje na innowacje, choć nie spełniają powyższych warunków. Niniejsza praca dotyczy warunku (b) i (c).

Skutecznością (ang. efficacy, effectiveness) działania (warunek b) nazywa się jego funkcję polegającą na tym, że osiąga ono lub jest w stanie osiągnąć swój cel [Simon, 1992: 577-578; 1997: 250-272]. Odróżnia się cel działania od jego intencji, a cel innowacji od motywu ich stworzenia. Motywy mogą być różnorodne. Innowacje mają pewien cel - polegający na rozwiązaniu jakiegoś problemu. Warunek (b) określa się ze względu na problem, którego rozwiązanie stanowi innowacja. Może się zdarzyć, że jej cel jest inny niż motywy jej twórcy, gdy rozwiązuje problem bez zamiaru jego rozwiązania. Na przykład Alexander Fleming wynalazł penicylinę, poszukując szczepionki na tyfus, Wilhelm Roentgen przypadkowo skonstruował pierwszy aparat do prześwietleń, gdy przeprowadzał rutynowy eksperyment $\mathrm{z}$ użyciem promieni katodowych, John Pemberton nie wiedział o tym, że tworzy napój orzeźwiający (Coca-Cola), gdy opracowywał recepturę leku na bóle głowy. Warunek (b) może obejmować możliwości wdrożeniowe innowacji [Frankelius, 2009: 49; Mansfield, 1968: 83]. W tym ujęciu np. projekty maszyn latających Leonarda da Vinci nie stanowiły innowacji w jego czasach, ale potem, gdy były już dostępne możliwości techniczne ich budowy i produkcji, te pomysły stały się innowacjami.

Przyjęto (c), że warunkiem koniecznym zjawiska innowacji jest jego (faktyczna lub przewidywalna) pożyteczność (użyteczność) - innowacja jest zmianą na lepsze. Odróżnia się zysk od pożytku. Zyskiem nazywa się przypadki, w których pod jakimiś względem korzyści jest więcej niż strat, np. zysk finansowy lub wizerunkowy, zysk jednostki, grupy lub organizacji itp. Pożytkiem nazywa się przypadki, w których we wszystkich relewantnych aspektach suma korzyści jest większa niż suma strat. W tym ujęciu pożytek jest rodzajem zysku, ale nie każdy zysk jest pożyteczny. Na przykład nie jest pożyteczną zmiana, która daje zysk dla organizacji, ale prowadzi do kryzysu gospodarczego. Praca przytacza przykłady

1 Definicje regulujące stanowią propozycję konwencji językowej, której nie ocenia się pod względem prawdy lub fałszu [Lycan, 1994: 263-289]. 
koncepcji określających relewantne aspekty, które należy uwzględnić w ocenie pożytku płynącego ze zmian oraz wskazuje założenia etyczne oceny innowacji pod względem tego, czy są pożyteczne.

\section{Podmiot korzyści i strat}

Precyzując warunek (c), należy odpowiedzieć na pytanie, czyj zysk brać pod uwagę w ocenie pożytku płynącego ze zmian. Co prawda zysk zwykle mierzy się na poziomie organizacji badź jej samodzielnych jednostek biznesowych i operacyjnych, ale można go też określać dla innych podmiotów. Inny może być zysk płynący z innowacji dla jej twórcy, dla organizacji, która z niej korzysta, jej inwestorów, interesariuszy i społeczeństwa. Przykładowo opracowanie nowego algorytmu obliczania szkodliwości spalin, który sprzyja sprzedaży aut, może być zyskowny dla ich producenta, ale nie musi być takim dla ich użytkowników i społeczeństwa [Adams, 2015]; praktyka zakłócania kompatybilności programów komputerowych ze starszymi wersjami systemu operacyjnego jest zyskowna dla producenta komputerów (gdyż zwiększa popyt na te produkty), ale dla użytkowników może generować straty większe od korzyści; inny jest zysk dla społeczeństwa płynący z otwartego dostępu w nauce, a inny - dla wydawnictw [Grant-Kels, 2017; Schekman, 2013].

Odpowiedź na powyższe pytanie zależy m.in. od rozstrzygnięć o charakterze etycznym. Przykładowo teoria etycznego egoizmu utożsamia pożytek (użyteczność) i zysk. Stanowisko opiera się na założeniu, że pożytek ze zmian zależy od tego, co jest $\mathrm{w}$ interesie jednostki lub grupy [Shaver, 2015]. Etyczny egoizm w radykalnej postaci był poddany krytyce, która pokazała m.in., że na gruncie powyższego założenia można usprawiedliwić wyzysk i przemoc. Umiarkowane teorie etycznego egoizmu mogą się przed tym zarzutem skutecznie bronić, np. przyjmując założenie, że egoistyczna motywacja racjonalnych jednostek skutkuje ich pożytecznymi społecznie działaniami, ale wtedy to stanowisko zbliża się do społecznego utylitaryzmu, o którym zaraz będzie mowa. Poza tym w drodze fenomenologicznej analizy intencjonalności aktów człowieka m.in. Immanuel Kant i George Edward Moore pokazują, że etyczny egoizm przeczy niektórym warunkom (racjonalnego) podejmowania decyzji, dlatego prowadzi do sprzeczności w teorii działania - sprzeczne oceny pożytku mogą być równie uzasadnione w myśl tej koncepcji [Anderson, 1995: 190-192; Fleurbaey, 2016; Frankena, 1973; Kant, 1984; Kelly, 2005; Moore, 1919; Okun, 2010; Piderit, 1993: 284-286; Shaver, 2015]. Te spostrzeżenia są punktem wyjścia różnorodnych propozycji wyjścia w teorii i praktyce poza egoistyczną perspektywę oceny pożytku. Przedstawiciele społecznego utylitaryzmu (ang. social utlilitarianism) zakładają, że ta ocena powinna uwzględniać korzyści i straty wszystkich ludzi, którzy coś tracą lub zyskują w wyniku zaistnienia ocenianego zjawiska. W tym duchu choćby koncepcje „społecznej odpowiedzialności biznesu” i „zrównoważonego rozwoju" promują poszerzenie perspektywy planowania o aspekt społecznych korzyści 
i strat [Melé, 2008]; Henry Mintzberg [1982: 104]. Zgodnie tym ujęciem, w ocenie pożytku zmian uwzględnić należy wartości społeczne (ang. social values), a m.in. koncepcja wydajności alokacyjnej Vilfreda Pareto przekłada ideę społecznej użyteczności na język ekonomii [Wight, 2015, 2017].

Koncepcja społecznego utylitaryzmu była krytykowana m.in. z tego powodu, że na jej gruncie można usprawiedliwić dyskryminację grup lub jednostek, gdy jest korzystna dla większości [Dworkin, 1990; Fleurbaey, 2014]. Dlatego tę teorię uzupełnia się lub zastępuje koncepcjami uwzględniającymi różnie pojmowane dobra „wewnętrzne” w ocenie użyteczności. Niektóre teorie personalizmu kierują się założeniem o przyrodzonej godności (każdego) człowieka, która stanowi uzasadnienie podstawowych praw człowieka określających konieczne warunki pożytku i kryteria jego oceny. W kontekście Arystotelesowskiego eudajmoni-

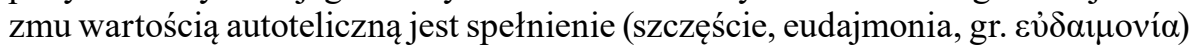
ludzkiej natury w każdym człowieku i ono jest miarą użyteczności. Liberalizm etyczny zakłada, że wartością autoteliczną jest wolność jednostek i pożytek zmian należy oceniać ze względu na to, czy promują one tę wartość. I tak dalej. Wyżej wskazane antyegoistyczne koncepcje nie przeczą możliwości szacowania zysku dla wybranego podmiotu z pominięciem innych. Pokazują jedynie, że ocena pożytku wychodzi poza perspektywę zysku wybranych jednostek i grup [Anderson, 1995: 190-192; Fleurbaey, 2016; Frankena, 1973; Kelly, 2005; Okun, 2010; Piderit, 1993: 284-286; Shaver, 2015].

\section{Temporalny aspekt oceny korzyści i strat}

Korzyści i straty bada się w określonej perspektywie czasowej. Jej wybór może być podyktowany założeniami etycznymi. Chociażby w kontekście etycznego egoizmu: korzyści i straty określa się dla jednostki lub grupy jednostek, a więc w perspektywie przewidywanego czasu ich życia. $Z$ kolei przy założeniu np. społecznego utylitaryzmu lub personalizmu pożytek należy określać dla wszystkich ludzi, także tych, którzy się jeszcze nie urodzili. To rozstrzygnięcie odgrywa ważną rolę przy podejmowaniu decyzji gospodarczych i politycznych, bo inne zjawiska mogą być pożyteczne w czasie życia jednostki lub grupy, a inne - w dalszej perspektywie. Przykładowo niektóre ekologiczne nurty etyki uzasadniają postulat ochrony przyrody dobrem przyszłych pokoleń [Daly, Townsend, 1996].

\section{Miara korzyści i strat}

Teorie etyczne dają różnorodne i częściowo rozbieżne odpowiedzi na pytanie o naturę korzyści i strat oraz sposób ich szacowania. Antyrelatywiści etyczni zakładają, że niektóre dobra są cenne niezależnie od ludzkich preferencji. Relatywiści etyczni przyjmują, że wartości są funkcją preferencji (jednostki lub 
grupy) - są cenne dlatego jedynie i o tyle tylko, o ile ktoś je ceni lub kieruje się nimi w podejmowaniu decyzji. Te założenia prowadzą do rozbieżnych rozwiązań w praktyce. Arystotelesowski eudajmonizm i nawiązujące do niego niektóre nurty personalizmu prezentują stanowisko antyrelatywistyczne, przyjmują, że miarą pożytku jest rozwój człowieka, pojmowany jako realizacja jego najcenniejszych możliwości (eudajmonia). Dlatego w ramach tej teorii odróżnia się rzeczywiste potrzeby (których zaspokojenie sprzyja tak rozumianemu rozwojowi) od potrzeb pozornych (urojonych, iluzorycznych) i pożytek wiąże się z zaspokojeniem jedynie tych pierwszych. Natomiast w kontekście tych koncepcji etycznego liberalizmu, które przyjmują stanowisko etycznego relatywizmu, odróżnienie potrzeb rzeczywistych od pozornych jest bezzasadne, bo zakłada się, że potrzeby są funkcją decyzji i każda z nich wyznacza jakiś cel, którego osiągnięcie jest potrzebą jej podmiotu. Dlatego w myśl tego założenia nie ma nic złego w kreowaniu potrzeb konsumentów przez przekonanie ich, że czegoś potrzebują. Można zatem odpowiednią kampanią reklamową promować bezużyteczny lub szkodliwy produkt, a wywołane w ten sposób decyzje zakupowe konsumentów nazwać ich „potrzebami”. W kontekście Arystotelesowskiego eudajmonizmu taka praktyka jest moralnie naganna, jeśli wywołuje poczucie takiej potrzeby, której zaspokojenie ogranicza możliwości rozwojowe człowieka [Blecker i in., 2006: 6373; Brink, 2014; Crisp, 2016; Monteskiusz, 1927: 51, 107].

Założenia etyczne wyznaczają metodę badania korzyści i strat. W kontekście hedonistycznego utylitaryzmu miarą pożytku jest sumaryczna ilość przyjemności i cierpień, co znaczy, że można mierzyć go empirycznie - badając wrażenia zadowolenia ludzi [Hennessy, 2000]. W ramach etycznego emotywizmu wartości są funkcją emocji, więc pożyteczność zjawisk można empirycznie badać, sprawdzając emocjonalny stosunek ludzi do następstw tego, co podlega ocenie. W ramach etycznego liberalizmu korzyści i straty określa się ze względu na preferencje ludzi, a więc pożytek czegoś można szacować ze względu na to, jak ludzie to oceniają (np. przez sondaż opinii). Teorie nawiązujące do eudajmonizmu Arystotelesa wymagają określania pożytku zmian pod względem tego, czy służą rozwojowi człowieka, a więc wpierw określa się metafizycznie rozumianą naturę człowieka (warunki człowieczeństwa), przekłada się jej pojęcie na język praktyki przy pomocy norm zgodności działania $\mathrm{z}$ tak rozumianą jego naturą (tzw. prawo naturalne), a następnie sprawdza się, czy zmiany są zgodne z tymi normami [Brink, 2014].

Pomimo tych rozbieżności przedstawiciele powyższych teorii zgodnie przyjmują, że korzyści i strat nie da się oszacować bez założenia jakiejś uporządkowanej (nieimplikującej logicznych lub praktycznych sprzeczności) hierarchii wartości (dóbr) oraz przyjęcia, że niektóre z nich są na szczycie tej hierarchii (są najcenniejsze, autoteliczne, wewnętrzne) [Brandt, 1967; Brown, 2008; Garnett, 1944; Gowans, 2012; Hollis, Lukes, 1982; Jarvie, 1983; Swoyer, 2014; Westacott, 2012]. Jak pokazuje np. Max Weber, założenia etyczne są nieuniknione w ocenie sukcesu (niem. Erfolg) działania, bo dotyczy ona nie tylko jego skuteczności - tj. tego, czy prowadzi ono do obranego przez jego podmiot celu - lecz także tego, czy planowane działanie nie unicestwi wartości równie ważnych lub ważniejszych od tego celu. Zgodnie z zasadą uwolnienia (niem. Wertfreiheit) nauk społecznych 
od aksjologicznych założeń Weber nie odpowiada na pytanie, jaką hierarchią wartości należy się kierować w ocenie sukcesu działania. Jednak zgodnie z jego sugestią ocenę korzyści i strat oprzeć należy na jakichś założeniach etycznych, które określą hierarchię wartości i naturę dóbr znajdujących się na jej szczycie [Albert i in., 2005; Kim, 2007; Oakes, 2003: 38-41; Weber, 1985: 565]. Te założenia powinny być racjonalne - odpowiednio uzasadnione. Takie ujęcie oceny sukcesu funkcjonuje we współczesnych teoriach zarządzania i ekonomii [Ackoff, Rovin, 2003; Coughlin, 1991; Cowan, Rizzo, 1995; Danielson, 1998; Gustafson, Johnson, 1989; Herman, 2014; Klimczak, 2014; Piderit, 1993; Pruzan, 1998; Segerstrom, 1990; Wight, 2015], choć jest on określany różnymi terminami (por. przyp. 2).

\section{Ewaluacja prawdopodobieństwa korzyści i strat}

Ocena tego, czy zmiany będą pożyteczne w przyszłości, wymaga oszacowania prawdopodobieństwa ich następstw. Zgodnie z zasadą ograniczonej racjonalności (ang. bounded rationality) wiedza o nich nie jest pewna - ma ograniczenia związane z niepewnością prognoz. W myśl tej zasady zmiany dające duże szanse korzyści i niosące małe ryzyko strat należy ocenić jako pożyteczniejsze od rozwiązań dających małe szanse korzyści i niosące duże ryzyko strat [Simon, 1992].

Ocena prawdopodobieństwa nie zależy od założeń etycznych, gdy dotyczy możliwości wystąpienia faktów. Jednak jeśli przewidywania dotyczą wartości, wtedy należy dokonać ewaluacji szans i ryzyka w myśl zasady, że im wyższa wartość ma szansę realizacji, tym ta możliwość jest cenniejsza, a im wyższa wartość jest zagrożona, tym ryzyko jej unicestwienia jest mniej dopuszczalne. W tym przypadku szanse i ryzyko szacuje się ze względu na przyjętą (wprost lub domyślnie) w ocenie hierarchię wartości, o której mówią założenia etyczne [Ackoff $i$ in., 2006; Ericson, Doyle, 2003; Federation of European Risk Management Association, 2003: 10; Frenkel i in., 2004]. Dlatego pewność przewidywań nie jest jedyną miarą oceny pożytku. W pewniejszy sposób można przewidzieć choćby korzyści płynące $\mathrm{z}$ badań stosowanych niż podstawowych, co nie znaczy, że badania podstawowe są mniej pożyteczne od stosowanych. Może się zdarzyć, że ze względu na wysoką rangę jakiejś wartości szacuje się wysoko szanse mało prawdopodobnego sukcesu i finansuje się kosztowne badania, które mają nieduże szanse powodzenia. Technologie Internetu i wiele innych innowacji opracowywano wpierw dla ochrony bezpieczeństwa państw (na potrzeby armii). Być może gdyby nie chodziło o tak wysoką wartość, jak zbiorowe bezpieczeństwo, zaniechano by pracy nad tymi innowacjami, gdyż ich stworzenie było bardzo kosztowne i obarczone dużym ryzykiem niepowodzenia. Uzasadnienia decyzji o ich finansowaniu należy upatrywać w przyjętej hierarchii wartości. 


\section{Etyczne założenia oceny wydajności}

Wskazane we wprowadzeniu warunki (b) i (c) łącznie dotyczą wydajności (ang. efficiency, productivity, economy), rozumianej jako zdolność działania zmierzającego do osiągnięcia zamierzonego celu w sposób możliwie najmniej kosztowny i najbardziej korzystny (koszty i korzyści mają aspekty ilościowe i jakościowe) ${ }^{2}$.

Ogólne pojęcie wydajności jest etycznie neutralne (nie implikuje żadnej oceny etycznej), gdyż nie określa tego, o czyje i o jakie korzyści oraz straty w nim chodzi oraz jaką miarą należy je szacować [Simon, 1992: 585-586; 1997: 250-272]. Jak pokazuje m.in. Mintzberg [1982], operacjonalizacja tego pojęcia nie jest możliwa bez przyjęcia założeń etycznych precyzujących to, jak należy pojmować pożytek: pojęcie wydajności, gdy przestaje być abstrakcyjne i zaczyna służyć opisowi oraz ocenie realnych zmian, nabiera znaczenia moralnego, bo ocena ich wydajności wymaga oszacowania pożytku z nich płynącego w świetle przyjętej hierarchii wartości, która jest wyznaczona etycznymi założeniami. Jeśli nie określi się ich wprost, są obecne domyślnie w ocenie wydajności działania. Przykładowo jeśli wydajność zmiany ocenia się ilościowo, to zakłada się tym samym, że inne niż ilościowo mierzalne wartości są mniej ważne w tej ocenie [Mintzberg, 1982: 104].

Podobnie w matematycznej teorii gier, ogólne pojęcie optymalnej i dominującej strategii działania jest etycznie neutralne, ale przy rozwiązywaniu konkretnych dylematów należy określić to, jakie są preferencje graczy. Jeśli się tego nie zrobi, dylematy prowadzą do paradoksów [Basu, 1988, 1994; Jacko, 2009]. Preferencje graczy obejmują m.in. ich hierarchię wartości. Określające ją etyczne założenia są domyślną przesłanką rozwiązań tej teorii.

Jak pokazuje m.in. Mintzberg, brak refleksji nad założeniami etycznymi decyzji może skutkować przeszacowaniem lub niedoszacowaniem przewidywanych korzyści lub strat, arbitralnym cenzurowaniem pomysłów lub życzeniowym przypisywaniem im wartości (której nie posiadają), co może skutkować poświęcaniem wartości wyżej cenionych dla realizacji wartości mniej cenionych i prowadzić do tego, że nie dostrzega się innowacyjności rozwiązań lub pochopnie uznaje się coś za innowację. Dlatego jego zdaniem należy określić te założenia, by móc ocenić wydajność zmian [Mintzberg, 1982: 104].

Założenia etyczne mogą decydować o tym, jakie jest praktyczne znaczenie doktryn politycznych i ekonomicznych. Na przykład operacjonalizacji postulatów ekologii służą te przesłanki: jeśli uzna się, że stan naturalny jest wartością

2 Takie rozumienie wydajności jest zgodne z tradycją językową obowiązującą m.in. w ekonomii i teoriach podejmowania decyzji [Simon, 1992: 577-578; 1997: 250-272]. Pojęcie to można rozumieć inaczej, niż tu zaproponowano. Są opracowania dotyczące jego wieloznaczności [np. Pyszka, 2015]. Na przykład za Peterem Druckerem można odróżniać efektywność (ang. effectiveness, productivity) działania jako realizację tego, co słuszne (ang. doing the right thing), czyli zgodne z etycznymi założeniami przyjmowanymi w ocenie, od wydajności (ang. efficiency) rozumianej jako proceduralna poprawność, polegająca na zgodności działania z jego założeniami (ang. doing things right) [Drucker, 2003; The Pennsylvania State University, 2006]. W pracy nie korzysta się z tej konwencji językowej. 
autoteliczną (najważniejszą), to tym samym zakłada się, że można go chronić kosztem innych wartości (np. w sposób szkodliwy społecznie); jeśli natomiast przyjąć, że przyroda jest wartością instrumentalną, to postulat jej ochrony wymaga takiego działania, by go realizować w sposób służący wartościom autotelicznym (np. by było pożyteczne społecznie) [Daly, Townsend, 1996].

Artykułowanie założeń etycznych odgrywa ważną rolę w komunikacji społecznej, gdyż one określają to, jakie zamiary kryją się za deklaracjami. Przemilczenie tych przesłanek może prowadzić do nieporozumień polegających chociażby na tym, że strony ulegają złudzeniu, iż osiągnęły konsensus w sprawie promowania innowacji, gdy w rzeczywistości go nie osiągnęły, bo rozbieżnie pojmują pożytek. Takie przemilczenie może też być przejawem manipulacji, gdy ktoś celowo wykorzystuje wieloznaczność terminów takich jak ,innowacje”, ,innowacyjność”, „pożytek” lub „wydajność” itp., by ukrywać swe zamiary przed społeczeństwem [Berkun, 2008; Dance, 2008]. Wyrażone wprost założenia etyczne można badać i negocjować - dają pole do stworzenia konsensusu w ich sprawie. Przemilczane - są poza społeczną kontrolą [Mintzberg, 1982: 104].

Jeśli uznać, że założenia etyczne są nieuniknione lub przynajmniej - potrzebne w teorii i praktyce dotyczącej innowacji, to należy te założenia badać pod względem ich znaczenia i zasadności. Dyskusja nad metodą takich badań wykraczałaby poza tematykę niniejszego opracowania i nie będzie się jej tutaj szczegółowo omawiać, ograniczywszy analizy do zasygnalizowania jakościowego aspektu oceny zmian.

\section{Jakościowy aspekt oceny wydajności}

Metody jakościowe niosą ryzyko arbitralności. To jest ich słaba strona. Jednak jak uważa m.in. Mintzberg [1982], nie należy z nich pochopnie rezygnować w ocenie zmian. Jego zdaniem ocena wydajności działania dokonywana wyłącznie za pomocą metod ilościowych niesie trzy zagrożenia. Po pierwsze, łatwiej jest określić tymi metodami korzyści i straty płynące ze zmiany dla danej organizacji, a trudniej je oszacować dla społeczeństwa. Dlatego ilościowa ocena wydajności zmian może usprawiedliwiać praktykę promowania zysku instytucji kosztem społeczeństwa [Mintzberg, 1982: 104]. Po drugie, zaniechanie metod jakościowych w ocenie zmian prowadzi do marginalizowania ich jakościowych aspektów, a to może prowokować do promowania zmian ilościowych kosztem potrzebniejszych zmian jakościowych, dlatego że te ostanie wymykają się ilościowej ocenie [Mintzberg, 1982: 101, 104]. Po trzecie, taka praktyka może prowokować organizacje i potencjalnych twórców innowacji do zaniechania pracy nad pomysłami potrzebnych zmian jakościowych [Mintzberg, 1982: 105].

Nie ulega kwestii, że metody ilościowe są cennym osiągnięciem nowożytnej nauki i odniosły niekwestionowane sukcesy m.in. w ekonomii i zarządzaniu. Powyższe spostrzeżenia Mintzberga nie są krytyką tych metod. Wskazane przez niego zagrożenia pokazują, że ocena wydajności działania obejmuje prócz ilościowych także jakościowe aspekty. Dlatego, zwłaszcza jeśli zmiana dotyczy 
wysoko cenionych wartości, ilościowe metody oceny płynącego z niej pożytku należy wzbogacić odpowiednimi metodami jakościowymi [Crisp, 2016; Driver, 2014; Enrick, 1973; Frankelius, 2009; Kuipers, 1994; Mansfield, 1968; Parsons, 2001; Rothbard, 2007; White, 2012].

Jak zauważa Mintzberg, ocena wydajności opiera się na założeniach etycznych (implikuje jakąś hierarchię wartości). Ten autor sugeruje, by przyjąć w niej opcję społecznego utylitaryzmu i uznać wartości społeczne (ang. social values) za ważniejsze od zysku organizacji [Mintzberg, 1982: 104], choć - jak to pokazano w niniejszej pracy - jest to jedna z możliwych opcji aksjologicznych.

Wartości autoteliczne są przedmiotem badań etyki. Etyka opisowa bada preferencje ludzi dotyczące tych wartości, a zadaniem etyki normatywnej i metaetyki jest m.in. precyzowanie i uzasadnianie założeń etycznych oraz ich operacjonalizacja w postaci norm i kryteriów oceny działania. Jak pokazano w pracy, te założenia są obecne wprost lub domyślnie w ocenie wydajności działania i w ten sposób określają warunek (c) innowacji. Dlatego badania etyczne mogą i powinny towarzyszyć teorii zmian i praktyce promowania innowacji. Po pierwsze, etyka pozwala na częściowe uzasadnienie niektórych rozstrzygnięć normatywnych, np. przez określenie apriorycznych związków wyznaczających warunki decyzji (etyka zajmuje się m.in. wykrywaniem niedorzeczności w rozumowaniu i praktycznych sprzeczności w decyzjach). Po drugie, etyka operacjonalizuje założenia etyczne - pokazując implikowane ich przyjęciem lub przemilczeniem wnioski i działania. Po trzecie, etyka odgrywa rolę heurystyczną w teorii, tworzeniu i promowaniu innowacji, gdyż pozwala zobaczyć problemy i ich rozwiązania w perspektywie szerszej niż tylko ilościowa lub wyznaczona możliwością zysku [Coughlin, 1991; Cowan, Rizzo, 1995; Gustafson, Johnson, 1989; Herman, 2014, 2015; Jacko, 2018; Klimczak, 2014; Piderit, 1993; Pruzan, 1998; Segerstrom, 1990; Wight, 2015; Zsolnai, 2013].

\section{Zakończenie}

Analizy zaprezentowane w niniejszej pracy kierują się założeniem, że innowacje są zmianami na lepsze, dlatego uznanie czegoś za innowację wymaga oszacowania pożytku, który z niej płynie. Wskazano niektóre etyczne założenia (dotyczące wartości autotelicznych), które wprost lub domyślnie są przyjmowane w ocenie innowacji pod tym względem. Pokazano niektóre teoretyczne i praktyczne implikacje tych założeń oraz niektóre ograniczenia ilościowych metod oceny wydajności zmian. W tym kontekście ukazano miejsce etyki w teoriach, badaniach i decyzjach dotyczących innowacji. 


\section{Bibliografia}

Ackoff R.L., Addison H.J., Magidson J. (2006), Idealized Design: Creating an Organization's Future, Upper Saddle River, Wharton School Publishing, New York.

Ackoff R.L., Rovin S. (2003), Redesigning Society, Stanford University Press, Stanford, California.

Adams C. (2015), Ethics versus Profit, ICAEW Economia, http://economia.icaew.com/features/december-2015/ethics-versus-profit [dostęp: 1.06.2017].

Albert G., Bienfait A., Sigmund S., Wendt C. (Hrsg.) (2005), Das Weber-Paradigma: Studien zur Weiterentwicklung von Max Webers Forschungsprogramm, Mohr Siebeck, Tubingen.

Anderson E. (1995), Value in Ethics and Economics, Harvard University Press, Harvard.

Basu K. (1988), Paradoxes of Game Theory [w:] P. Newman (ed.), The New Palgrave Dictionary of Economics and the Law, vol. 3 (s. 1-5), Palgrave Macmillan UK, London.

Basu K. (1994), The Traveler's Dilemma: Paradoxes of Rationality in Game Theory, „The American Economic Review", 84(2), 391-395.

Berkun S. (2008), Stop Saying Innovation - Here's Why, http://scottberkun.com/2008/stopsaying-innovation-heres-why/ [dostęp: 3.06.2017].

Blecker T., Friedrich G., Kaluza B., Abdelkafi N., Kreutler G. (2006), Information and Management Systems for Product Customization, Springer Science \& Business Media, Boston.

Brandt R.B. (1967), Ethical Relativism [w:] P. Edwards (ed.), The Encyclopedia of Philosophy, vol. 3-4 (s. 75-78), McMillan: New York.

Brink D.O. (2014). Aristotelian Naturalism in the History of Ethics, ,Journal of the History of Philosophy", (52), 813-833.

Brown M.F. (2008), Cultural Relativism 2.0., „Current Anthropology”, 49(3), 363-383.

Coughlin R.M. (ed.) (1991), Morality, Rationality, and Efficiency: New Perspectives on SocioEconomics, M.E. Sharpe, Armonk, New York-London.

Cowan R., Rizzo M.J. (eds.) (1995), Profits and Morality, University of Chicago Press, Chicago.

Crisp R. (2016), Well-Being [w:] E.N. Zalta (ed.), The Stanford Encyclopedia of Philosophy, http://plato.stanford.edu/archives/sum2016/entries/well-being/ [dostęp: 1.06.2017].

Daly H.E., Townsend K.N. (eds.) (1996), Valuing the Earth: Economics, Ecology, Ethics, MIT Press Cambridge, London.

Dance J. (2008), What Is Innovation? 30+ Definitions Lead to One Fresh Summary, https:// www.freshconsulting.com/what-is-innovation/ [dostęp: 30.04.2017].

Danielson P. (ed.) (1998), Modelling Rationality, Morality, and Evolution, Oxford University Press, New York-Oxford.

Driver J. (2014), The History of Utilitarianism [w:] E.N. Zalta (ed.), The Stanford Encyclopedia of Philosophy, http://plato.stanford.edu/archives/win2014/entries/utilitarianism-history/ [dostęp: 1.06.2017].

Drucker, P. F. (2003). Menedżer skuteczny, tłum. J. Górski, J. Szyfter, Wydawnictwo MT Biznes, Warszawa.

Dworkin R. (1990), The “Double Counting” Objection [w:] J. Glover (ed.), Utilitarianism and Its Critics (s. 103-110), Macmillan, Collier, New York-London. 
Enrick N.L. (1973), Qualitative Values Into Quantitative Measures: Marketing Decisions Applications, ,Journal of the Academy of Marketing Science”, 1(2), 90-99.

Ericson R.V., Doyle A. (eds.) (2003), Risk and Morality, University of Toronto Press, Toronto-Buffalo-London.

Federation of European Risk Management Association (2003), Standard zarzadzania ryzykiem, http://www.ferma.eu/app/uploads/2011/11/a-risk-management-standard-polish-version.pdf [dostęp: 13.05.2017].

Fleurbaey M. (2014), The Facets of Exploitation, „Journal of Theoretical Politics”, 26, 653-676.

Fleurbaey M. (2016), Economics and Economic Justice [w:] E.N. Zalta (ed.), The Stanford Encyclopedia of Philosophy (Winter 2016), Metaphysics Research Lab, Stanford University, https://plato.stanford.edu/archives/win2016/entries/economic-justice/ [dostęp: 1.06.2017].

Frankelius P. (2009), Questioning Two Myths in Innovation Literature, „The Journal of High Technology Management Research", 1(20), 40-51.

Frankena W.K. (1973), Ethics, Prentice-Hall, http://www.ditext.com/frankena/ethics.html [dostęp: 1.06.2017].

Frenkel M., Hommel U., Rudolf M. (eds.) (2004), Risk Management: Challenge and Opportunity, Springer Science \& Business Media, Berlin-Heilderberg.

Garnett A.C. (1944), Relativism and Absolutism in Ethics, „Ethics”, 54(3), 186-199.

Gowans C. (2012), Moral Relativism [w:] E.N. Zalta (ed.), The Stanford Encyclopedia of Philosophy, http://plato.stanford.edu/archives/spr2012/entries/moral-relativism/ [dostęp: 1.06.2017].

Grant-Kels J.M. (2017), The Ethical Arguments in Support of Open Access Journals, „International Journal of Women's Dermatology", 3(1), 4-5.

Gustafson J.M., Johnson E.W. (1989), Efficiency, Morality, and Managerial Effectiveness, „Bulletin of the American Academy of Arts and Sciences”, 42(7), 9.

Hennessy R. (2000), Profit and Pleasure: Sexual Identities in Late Capitalism, Psychology Press, New York-London.

Herman A. (2014), Współzależność aksjologii wartości ekonomicznej z metodami jej pomiaru, „Kwartalnik Nauk o Przedsiębiorstwie”, 4(33), 2.

Herman A. (2015), Aksjologiczne aspekty teorii i praktyki zarzadzania wartościa, ,Kwartalnik Nauk o Przedsiębiorstwie", 35(2), 19-37.

Hollis M., Lukes S. (ed.) (1982), Rationality and Relativism, MIT Press, Cambridge.

Jacko J.F. (2009), Niektóre ontologiczne rozstrzygnięcia teorii gier na przykładzie dylematu podróżnika i dylematu więźnia, „Zagadnienia Naukoznawstwa”, 3-4(181-182), 429-441.

Jacko J.F. (2018), Moral Conditions for Methodologically Rational Decisions [w:] M. Hetmański (ed.), Rationality and Decision Making: From Normative Rules to Heuristics, vol. 111 (s. 209-223), Brill Rodopi, Leiden-Boston.

Jarvie I.C. (1983), Thinking About Society: Theory and Practice, R. Reidel Publishing Company, Dortrecht-Boston-Lancaster.

Kant I. (1984), Krytyka praktycznego rozumu, tłum. J. Gałecki, Państwowe Wydawnictwo Naukowe, Warszawa.

Kelly P. (2005), Liberalism, Polity, Cambridge.

Kim S.H. (2007), Max Weber [w:] E.N. Zalta (ed.), The Stanford Encyclopedia of Philosophy, http://plato.stanford.edu/archives/fall2013/entries/weber/ [dostęp: 1.06.2017]. 
Klimczak B. (2014), Aksjologiczne uwikłanie ekonomii, „Annales. Etyka w Życiu Gospodarczym", 17(1), 9-21.

Kożuch B. (2010), Innowacyjność w zarządzaniu publicznym [w:] A. Bosiacki, H. Izdebski, A. Nelicki, I. Zachariasz, Nowe zarzadzanie publiczne i public governance $w$ Polsce i $w$ Europie, Liber, Warszawa.

Kuipers B. (1994), Qualitative Reasoning: Modelling and Simulation with Incomplete Knowledge, MIT Press, Cambridge.

Lycan W.G. (1994), Modality and Meaning, Springer Science \& Business Media, DortrechtBoston-London.

Mansfield E. (1968), Industrial Research and Technological Innovation: An Econometric Analysis, W.W. Norton, New York.

Melé D. (2008), Corporate Social Responsibility Theories [w:] A. Crane, D. Matten, A. McWilliams, J. Moon, D. Siegel (eds.), The Oxford Handbook of Corporate Social Responsibility, Oxford University Press, Oxford-New York.

Mintzberg H. (1982), A Note on That Dirty Word “Efficiency”, „Interfaces”, 12(5), 101-105.

Monteskiusz [Charles de Montesquieu] (1927), O duchu praw, tłum. T. Boy-Żeleński, Warszawa, Wolne Lekury, https://wolnelektury.pl/katalog/lektura/o-duchu-praw.html [dostęp: 1.06.2017].

Moore G.E. (1919), Zasady etyki, tłum. C. Znamierowski, Wydawnictwo M. Arcta, Warszawa.

Oakes G. (2003), Max Weber on Value Rationality and Value Spheres: Critical Remarks, „Journal of Classical Sociology”, 3(1), 27-45.

Okoń-Horodyńska E. (2008), Edukacja dla innowacji. (Czy tylko wybrani skazani sq na sukces innowacyjny?), „Nauka i Szkolnictwo Wyższe”, 1(31), 34-54.

Okun A.M. (2010), Equality and Efficiency: The Big Tradeoff, Brookings Institution Press, Washington.

Parsons S. (2001), Qualitative Methods for Reasoning Under Uncertainty, MIT Press, Cambridge-Massachusetts-London.

The Pennsylvania State University (2006), Doing the Right Things Right: Enhanced Effectiveness and Cost Savings, ,Innovation Insight Series”, (6), 1-4, http://www.opia.psu.edu/ sites/default/files/insights006.pdf [dostęp: 1.06.2017].

Piderit J.J. (1993), The Ethical Foundations of Economics, Georgetown University Press, Washington.

Pruzan P. (1998), From Control to Values-Based Management and Accountability, ,Journal of Business Ethics", 17(13), 1379-1394.

Pyszka A. (2015), Istota efektywności. Definicje i wymiary, „Studia Ekonomiczne”, 230, $13-25$.

Rothbard M.N. (2007), Utilitarian Free-Market Economics, „Mises Daily Articles”. https:// mises.org/library/utilitarian-free-market-economics [dostęp: 1.06.2017].

Schekman R. (2013), How Journals Like Nature, Cell, and Science Are Damaging Science, „TheGuardian”, https://www.theguardian.com/commentisfree/2013/dec/09/how-journalsnature-science-cell-damage-science [dostęp: 1.06.2017].

Schroeder M. (2012), Value Theory [w:] E.N. Zalta (ed.), The Stanford Encyclopedia of Philosophy (Summer 2012), http://plato.stanford.edu/archives/sum2012/entries/value-theory/ [dostęp: 1.06.2017].

Segerstrom P.S. (1990), Moral Efficiency. „Social Choice and Welfare”, 7(2), 109-129. 
Shaver R. (2015), Egoism [w:] E.N. Zalta (red.), The Stanford Encyclopedia of Philosophy https://plato.stanford.edu/archives/spr2015/entries/egoism/ [dostęp: 1.06.2017].

Simon H.A. (1992), Methodological Foundations of Economics [w:] J.L. Auspitz, W. Gasparski, M. Mlicki, K. Szaniawski (eds.), Praxiologies and the Philosophy of Economics (s. 25-42), Transaction Publishers, New Brunswick, New Jersey.

Simon H.A. (1997), Administrative Behavior (4th ed.), The Free Press, New York.

Swoyer C. (2014), Relativism [w:] E. N. Zalta (ed.), The Stanford Encyclopedia of Philosophy (T. Spring 2014 Edition), http://plato.stanford.edu/archives/spr2014/entries/relativism/ [dostęp: 1.06.2017].

Świtała I.M. (2015), Praca człowieka $w$ wymiarze autotelicznym i instrumentalnym - wybrane aspekty aksjologii pracy, „Edukacja Ustawiczna Dorosłych”, 88(1), 57-68.

Walshe K. (2009), Pseudoinnovation: The Development and Spread of Healthcare Quality Improvement Methodologies, „International Journal for Quality in Health Care”, 21(3), 153-159.

Weber M. (1985), Gesammelte Aufsätze zur Wissenschaftslehre, Mohr Siebeck, Tübingen.

Westacott E. (2012), Internet Encyclopedia of Philosophy, http://www.iep.utm.edu/moral-re/ [dostęp: 1.06.2017].

White M.D. (2012), Value in Economics: Accentuate the Qualitative, but Don't Eliminate the Quantitative [w:] I. Gennaro (ed.), Value. Sources and Readings on a Key Concept of the Globalized World (s. 331-347), Brill, Leiden.

Wight J.B. (2015), Ethics in Economics: An Introduction to Moral Frameworks, Stanford University Press, Stanford, California.

Wight J.B. (2017), The Ethics Behind Efficiency, „The Journal of Economic Education”, 48, 15-26.

Zimmerman M.J. (2001), The Nature of Intrinsic Value, Rowman \& Littlefield, Lanham.

Zsolnai L. (ed.) (2013), Handbook of Business Ethics - Ethics in the New Economy, Peter Lang International Academic Publishers, Oxford. 